\title{
A Systematic Review of the Role of Robotics in Plastic and Reconstructive Surgery-From Inception to the Future
}

\author{
Thomas D. Dobbs ${ }^{1,2 *}$, Olivia Cundy ${ }^{3}$, Harsh Samarendra ${ }^{3}$, Khurram Khan ${ }^{4}$ \\ and lain Stuart Whitaker ${ }^{1,2}$
}

${ }^{1}$ Reconstructive Surgery and Regenerative Medicine Research Group (ReconRegen), Institute of Life Science, Swansea University Medical School, Swansea, United Kingdom, ${ }^{2}$ The Welsh Centre for Burns and Plastic Surgery, Morriston Hospital, Swansea, United Kingdom, ${ }^{3}$ Oxford University Medical School, Oxford, United Kingdom, ${ }^{4}$ Department of Plastic Surgery, Birmingham Children's Hospital, Birmingham, United Kingdom

Background: The use of robots in surgery has become commonplace in many special-

OPEN ACCESS

Edited by:

Vincenzo Neri,

University of Foggia, Italy

Reviewed by:

David J. Hunter-Smith,

Monash University Plastic

and Reconstructive Surgery Group,

Australia

Oren Lapid,

Academic Medical Center

(AMC), Netherlands

Jeffrey $B$. Friedrich,

University of Washington Tacoma,

United States

*Correspondence:

Thomas D. Dobbs

tomdobbs@doctors.org.uk

Specialty section:

This article was submitted to Reconstructive and Plastic Surgery,

a section of the journal

Frontiers in Surgery

Received: 29 September 2017 Accepted: 01 November 2017

Published: 15 November 2017

Citation:

Dobbs TD, Cundy O, Samarendra H,

Khan K and Whitaker IS (2017)

A Systematic Review of the

Role of Robotics in Plastic and

Reconstructive Surgery-From

Inception to the Future.

Front. Surg. 4:66.

doi: 10.3389/fsurg.2017.00066 ties. In this systematic review, we report on the current uses of robotics in plastic and reconstructive surgery and looks to future roles for robotics in this arena.

Methods: A systematic literature search of Medline, EMBASE, and Scopus was performed using appropriate search terms in order to identify all applications of robotassistance in plastic and reconstructive surgery. All articles were reviewed by two authors and a qualitative synthesis performed of those articles that met the inclusion criteria. The systematic review and results were conducted and reported in accordance with the Preferred Reporting Items for Systematic Reviews and Meta Analysis (PRISMA) guidelines.

Results: A total of 7,904 articles were identified for title and abstract review. Sixty-eight studies met the inclusion criteria. Robotic assistance in plastic and reconstructive surgery is still in its infancy, with areas such as trans-oral robotic surgery and microvascular procedures the dominant areas of interest currently. A number of benefits have been shown over conventional open surgery, such as improved access and greater dexterity; however, these must be balanced against disadvantages such as the lack of haptic feedback and cost implications.

Conclusion: The feasibility of robotic plastic surgery has been demonstrated in several specific indications. As technology, knowledge, and skills in this area improve, these techniques have the potential to contribute positively to patient and provider experience and outcomes.

Keywords: robotic surgery, plastic surgery, microsurgery, head and neck, technology, innovation

\section{INTRODUCTION}

The use of robotics in surgery has captured the imagination of many. It is a growth area across the breadth of surgical specialties, with many procedures becoming routinely classed as "robot-assisted." The rapid increase in surgical research involving robotic assistance can be witnessed by the rising number of articles published in consecutive years related to the subject (Figure 1). 


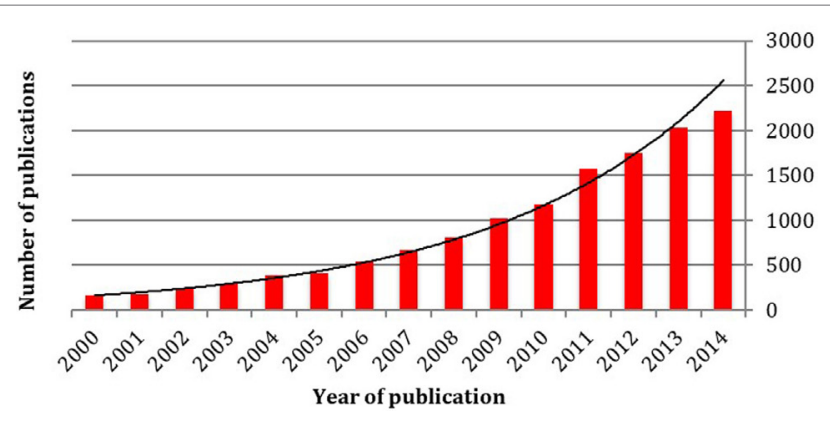

FIGURE 1 | A 15-year literature review of the number of publications relating to robotic surgery demonstrating a highly significant exponential increase. Each column represents the number of papers published in that year, rising from 168 in 2000 to over 2,000 in the year 2014 (Source; Pubmed, searched using the terms "robot" and "surgery" from January 2000 to December 2014)

Since the first reported use of the daVinci ${ }^{\circledR}$ Surgical Robotic System (Intuitive Surgical, Sunnyvale, CA, USA) in a roboticassisted laparoscopic cholecystectomy (1), Intuitive Surgical has become the leading force in surgical robotics. The daVinci ${ }^{\circledR}$ robot has been widely implemented in many surgical specialties, from cardiac surgery $(2,3)$ to gynecology $(4,5)$. In the USA, $80 \%$ of radical prostatectomies are now being performed robotically (6). With updates to the daVinci ${ }^{\circledR}$ robot including a fourth instrument arm, its application is broadening to other specialties such as colorectal surgery (7). The dominance of the daVinci ${ }^{\circledR}$ system is, however, beginning to be challenged with new competitors entering the market.

Plastic and reconstructive surgery is an innovative specialty, often at the forefront of technical innovation within surgery. It is also a specialty that works collaboratively with many other surgical disciplines and, therefore, those practicing it will likely come across advances in robotic surgery in these other specialties. It is, therefore, important for plastic surgeons to embrace this new surgical platform, explore potential uses for it, and learn from those who have already incorporated robotics into their surgical armamentarium.

This systematic review aimed to identify all current reported uses of robotic assistance in plastic and reconstructive surgery, from cadaveric to clinical examples. We have provided and upto-date list of all areas of interest to the plastic and reconstructive surgeon, evaluating the relevant advantages and disadvantages of the use of robotics in these areas.

\section{METHODS}

A database search was performed to identify all articles describing the use of robotic assistance in plastic and reconstructive surgery. The search strategy was constructed in line with the Preferred Reporting Items for Systematic Reviews and Meta Analysis (PRISMA) guidelines (8) and the Cochrane handbook (9). Key words and Medical Subject Heading terms were combined using Boolean logic and refined with the help of an information specialist (see Figure 2 for an example of the full search strategy).
Medline (1946-present), EMBASE (1980-present), and Scopus electronic databases were all searched using the developed search strategy up to May 2017.

All studies identified were downloaded into EndNote V8 for Mac (Clarivate Analytics) and duplicates removed. De-duplicated results were then uploaded to Covidence (www. covidence.org) for screening. Titles and abstracts were reviewed by two independent reviewers (OC and HS) against the inclusion and exclusion criteria and discrepancies resolved through discussion with a third, independent reviewer (TD). Studies were considered eligible for qualitative synthesis if they met the following inclusion criteria:

- the study was published in English

- the study design was one of the following: case reports, case cohorts, case-control and randomized controlled studies. Both prospective and retrospectively designed studies were included.

- the study reports the use of a robotic surgical system for a potential plastic surgery-related operation, with both preclinical and clinical applications included.

Full-text articles of those included studies were subsequently reviewed independently for final inclusion. References were checked for further, un-identified articles, and these were added in if appropriate.

A data extraction sheet was developed to extract the following data from studies: Author, date of publication, location of study, study design, number of operations performed, operations/ techniques, outcomes measured. This was piloted on a random sample of papers and subsequently refined. All data were extracted and tabulated using Microsoft Word and Excel (Redmond, Washington, DC, USA).

\section{RESULTS}

Figure 3 illustrates the PRISMA flow diagram demonstrating the process of article retrieval and screening. A total of 7,904 articles were identified after de-duplication for screening. Of these 213 made it to full-text review. A total of 68 studies met the inclusion criteria and were eligible for inclusion in this systematic review. Included papers were divided into groups based on operative type or body location and a qualitative synthesis of the outcomes reported performed.

\section{Microsurgery}

A total of 13 studies were identified discussing the use of robotics for a microsurgery application (Table 1). Eleven of these were preclinical studies in synthetic, animal, and cadaveric models (10-20) while two were clinical studies $(21,22)$. Katz et al. performed the first $\mathrm{daVinci}^{\circledR}$ system assisted anastomosis in a porcine model in 2005 (10), closely followed by work in canine tarsal and femoral vessels (13). In these studies, they concluded significant advantages such as the elimination of tremor at a microsurgical level, but that the lack of purpose-built microsurgical instruments was an important limitation. Further animal and human cadaveric work cemented the idea that robotically assisted microvascular surgery is both feasible and in some instances 


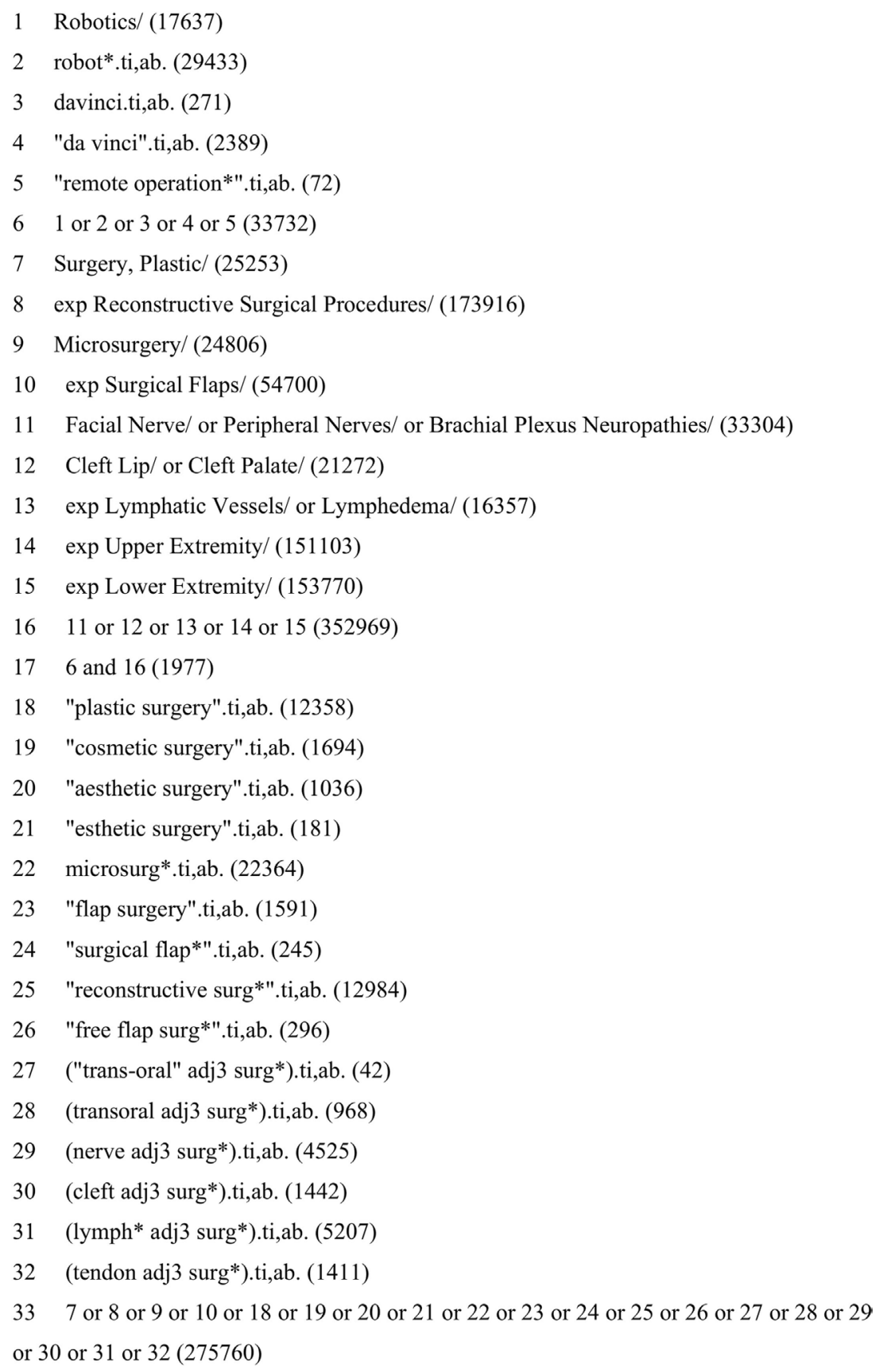

FIGURE 2 | Example search strategy performed in Medline. Searches conducted on 9.5.2017.

potentially beneficial, such as when working at depth and for surgeon comfort (20).

Two clinical examples were identified, with one cohort study by Boyd et al. including 22-patients where the robot was used for harvesting the internal mammary vessels in free breast reconstruction (21). Van der Hulst et al. used the robot to perform the anastomosis, commenting on the increased time taken for this over traditional methods, as would be expected early on in the learning curve (22). As in preclinical studies, the benefits of using the daVinci ${ }^{\circledast}$ robot for performing the microvascular anastomosis include elimination of tremor and motion scaling.

\section{Muscle Flap Harvest}

Traditionally muscle free-flaps are raised through a large incision overlying the muscle belly and are, therefore, a perfect example of where the robot can have marked benefit as minimally invasive harvesting can significantly reduce the size of externally visible scarring. Laparoscopic harvesting has been attempted, but with 


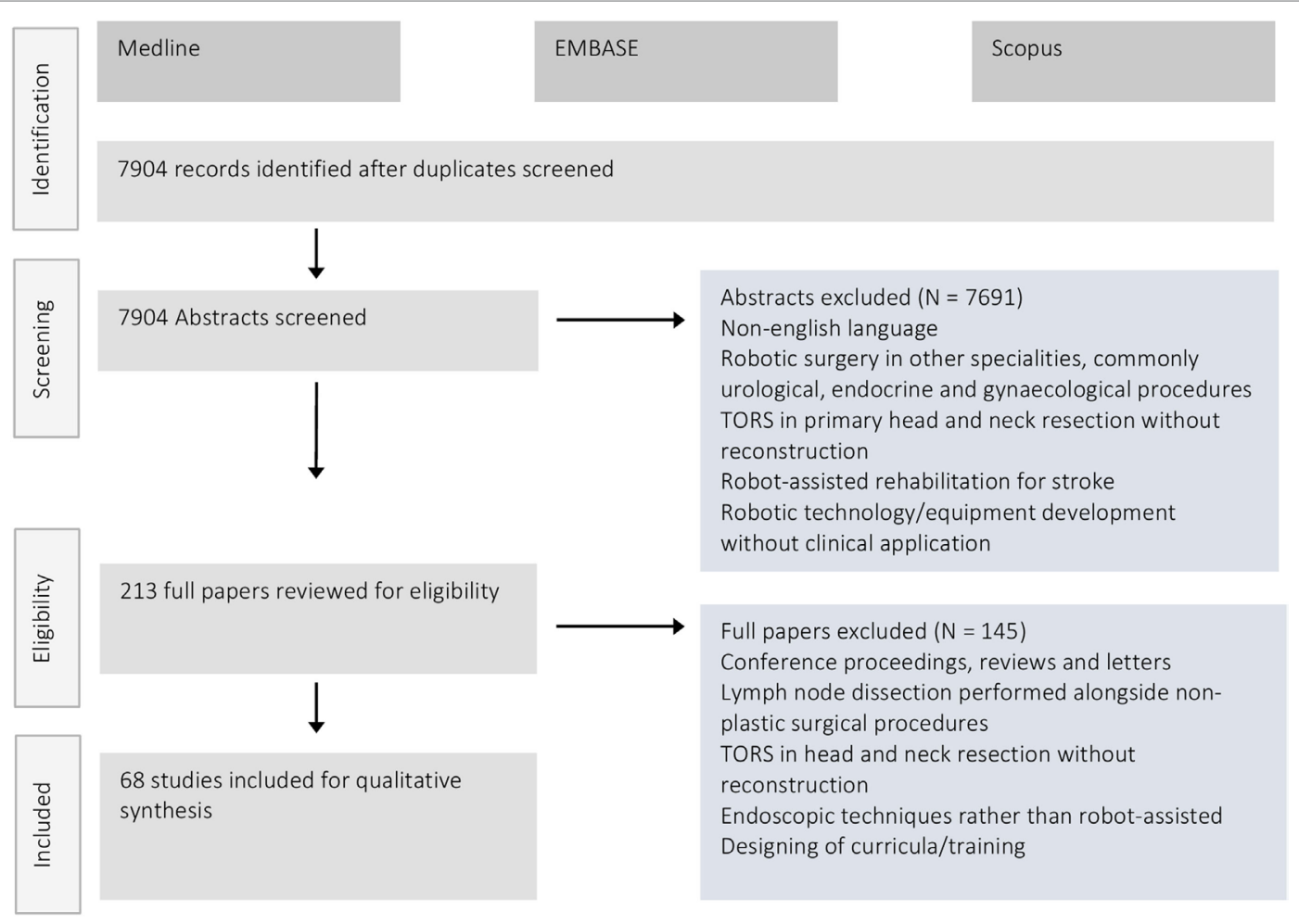

FIGURE 3 | PRISMA flow diagram demonstrating the number of retrieved articles, those screened and final number included in the systematic review after full-text review.

poor uptake due to difficulties with visualization of the operative field and the inherent limitations of laparoscopic instruments $(23,24)$. Three human cadaveric studies $(25-27)$ and five clinical reports (28-32) were identified describing the use of the robot for muscle flap harvest (Table 2). In those clinical studies, it is clear that the robot improves visualization, reduces the scar burden and resulted in reduced postoperative pain and hospital stay.

The traditional approach to rectus muscle harvest is with a large abdominal skin incision. Not only is this cosmetically unappealing but also, in combination with division of the anterior abdominal wall fascia, can result in incisional hernia formation. As robot-assisted colorectal surgery becomes increasingly routine, with the advantages of minimal scarring, reduced conversion to open procedure, reduced time to intestinal motility, and reduced postoperative sexual dysfunction reported (33), it would seem a retrograde step to then introduce a large abdominal wound when harvesting the rectus abdominis muscle for perineal reconstruction. In a case series by Singh et al. the robot was used in tandem with a robotically performed abdominoperineal resection for adenocarcinoma to raise the rectus abdominis flap for reconstruction (32). This produced satisfactory closure of the defect without the risk of a ventral hernia. In these combined procedures the risks associated with entering the abdominal cavity are already present from the colorectal resection and, therefore, one of the major disadvantages of robotically assisted rectus abdominis muscle harvest is not a risk purely implicated through the use of this novel muscle harvest technique.

\section{Nerve Surgery}

A total of eight preclinical studies and five clinical studies were identified, with the majority investigating the role of robotics in brachial plexus work (Table 3) (34-46). Epineural nerve repair using robotic assistance has been shown to be technically feasible in animal models, with the benefits of reduced physiological tremor and improved vision of the surgical field noted (35). Nerve harvest has also been demonstrated to be feasible in cadaveric and animal models $(35,37)$.

In those clinical studies identified, robotic assistance was successfully used to repair a brachial plexus (45), repair the sympathetic chain to treat Horner's syndrome (42), perform a thoracic sympathectomy for palmar hyperhidrosis (43), repair a peripheral nerve following tumor excision (46), and undertake an Oberlin procedure (44).

\section{Upper Limb}

Table 4 illustrates those articles relating to procedures in the upper limb, with three preclinical (47-49) and one clinical study identified (50). As with a number of other areas of the body the use of the robot has so far only been for proof of concept and there has yet to be any concrete studies demonstrating a benefit.

\section{Trans-Oral Robotic Surgery (TORS)}

Trans-oral robotic surgery has allowed head and neck surgeons to treat benign and malignant conditions of the oral 
TABLE 1 | Preclinical and clinical studies relating to the use of robotics in microvascular procedures.

\begin{tabular}{|c|c|c|c|c|}
\hline Reference & Year & Study design & Operations performed & Outcomes reported \\
\hline \multicolumn{5}{|l|}{ Preclinical studies } \\
\hline Katz et al. (10) & 2005 & Animal model & $\begin{array}{l}\text { Arterial and venous anastomoses and } \\
\text { free-flap transplantation } \\
(N=1 \text { pig) }\end{array}$ & $\begin{array}{l}\text { All anastomoses grossly patent, confirmed by audible Doppler } \\
\text { signals, visibly adequate perfusion of tissues, and arterial bleeding } \\
\text { seen after incision distal to the anastomoses } 4 \mathrm{~h} \text { after the } \\
\text { procedure }\end{array}$ \\
\hline Knight et al. (11) & 2005 & $\begin{array}{l}\text { Animal model } \\
\text { Case controlled }\end{array}$ & $\begin{array}{l}\text { Arterial end-to-end anastomoses } \\
(N=31 \text { vs } N=30 \text { controls })\end{array}$ & $\begin{array}{l}\text { A remarkable degree of tremor filtration, but significantly slower } \\
\text { operative time. All anastomoses were patent and non-leaking }\end{array}$ \\
\hline Karamanoukian et al. (12) & 2006 & $\begin{array}{l}\text { Animal tissue } \\
\text { samples }\end{array}$ & $\begin{array}{l}\text { Slit arteriotomy and end-to-end arterial } \\
\text { anastomoses in procine hearts }\end{array}$ & $\begin{array}{l}\text { The Zeus robotic system is a viable tool for microsurgical } \\
\text { vascular reconstruction. It allows for precise movement, lack } \\
\text { of hand tremor, enhanced microvascularisation and improved } \\
\text { ergonomics, compared to conventional human assistance. The } \\
\text { major advantage is the ability of the robot to scale down the } \\
\text { surgeon's movements to a microscopic level }\end{array}$ \\
\hline Katz et al. (13) & 2006 & Animal cadavers & $\begin{array}{l}\text { Microvascular anastomoses of tarsal } \\
\text { and superficial femoral vessels } \\
\text { ( } N=2 \text { dog cadavers) }\end{array}$ & All anastomoses were successful and patent postoperatively \\
\hline Taleb et al. (14) & 2008 & Animal cadaver & $\begin{array}{l}\text { Microvascular anastomoses in rat tail } \\
\text { transplantation }(N=2)\end{array}$ & $\begin{array}{l}\text { Immediate and delayed ( } 1 \mathrm{~h} \text { postoperation) patency of the arterial } \\
\text { anastomoses }\end{array}$ \\
\hline Ramdhian et al. (15) & 2011 & $\begin{array}{l}\text { Animal tissue } \\
\text { samples }\end{array}$ & $\begin{array}{l}\text { Earthworm segment anastomoses } \\
(N=15)\end{array}$ & $\begin{array}{l}\text { The high quality 3D vision allowed by the robotic system was } \\
\text { excellent and compensated for loss of tactile feedback. The } \\
\text { robotic system eliminated physiological tremor. Motion scaling by } \\
\text { the robot improved precision of the surgical gesture }\end{array}$ \\
\hline Lee et al. (16) & 2012 & Live animal models & $\begin{array}{l}\text { Femoral artery end-to-end } \\
\text { anastomoses }(N=20)\end{array}$ & $\begin{array}{l}\text { Generation of learning curves for robot-assisted microvascular } \\
\text { anastomosis. Important aspects of learning identified included } \\
\text { starting level, learning plateau and learning rate }\end{array}$ \\
\hline \multirow[t]{2}{*}{ Robert et al. (17) } & \multirow[t]{2}{*}{2013} & \multirow[t]{2}{*}{ Human cadaver } & \multirow[t]{2}{*}{$\begin{array}{l}\text { Radial/ulnar artery dissection and } \\
\text { microvascular anastomoses } \\
\text { ( } N=2 \text { cadavers, } 4 \text { anastomoses) }\end{array}$} & $\begin{array}{l}\text { Successful anastomoses } \\
\text { The assembling and disassembling of the vascular clamp were } \\
\text { time consuming }\end{array}$ \\
\hline & & & & $\begin{array}{l}\text { In both cases (radial and ulnar arteries), the 10/0 needle was bent } \\
\text { and a second suture had to be used }\end{array}$ \\
\hline Alrasheed et al. (18) & 2014 & $\begin{array}{l}\text { Synthetic vessel } \\
\text { models }\end{array}$ & $\begin{array}{l}\text { Microvascular anastomoses } \\
(N=50)\end{array}$ & $\begin{array}{l}\text { Successful validation of microsurgical assessment tool and } \\
\text { characterization of learning curve } \\
\text { Proficiency gained by operators over } 5 \text { learning sessions }\end{array}$ \\
\hline Selber and Alrasheed (19) & 2014 & Synthetic models & $\begin{array}{l}\text { Microvascular anastomoses } \\
(N=5 \text { per surgeon) }\end{array}$ & $\begin{array}{l}\text { Definition of a learning curve in microsurgery and the development } \\
\text { of a structured assessment of robotic microsurgical skills }\end{array}$ \\
\hline Willems et al. (20) & 2016 & $\begin{array}{l}\text { Synthetic } \\
\text { microvessel models } \\
\text { Case controlled }\end{array}$ & $\begin{array}{l}\text { Microvascular anastomoses } \\
(N=80, \text { vs } 80 \text { control) }\end{array}$ & $\begin{array}{l}\text { Manual surgery was superior to robotically assisted microsurgery } \\
\text { in technically easy exposures. In difficult exposures (greater } \\
\text { depth and lower sidewall angles), however, robotically assisted } \\
\text { microsurgery had a shorter surgery time and a higher comfort } \\
\text { rating. Objective Structured Assessment of Technical Skills scores } \\
\text { were similar to those assessing traditional microsurgery }\end{array}$ \\
\hline \multicolumn{5}{|l|}{ Clinical studies } \\
\hline Boyd et al. (21) & 2006 & $\begin{array}{l}\text { Case cohort, } \\
\text { retrospective }\end{array}$ & $\begin{array}{l}\text { Robotic vessel harvest of internal } \\
\text { mammary vessels for use in free-flap } \\
\text { breast reconstructive procedures } \\
\text { (11 muscle-sparing transverse rectus } \\
\text { abdominis musculocutaneous (TRAM) } \\
\text { flaps, six superior gluteal artery (SGA) } \\
\text { flaps, four superficial inferior epigastric } \\
\text { artery flaps, and one superior gluteal } \\
\text { arterial perforator flap) ( } N=22 \text { free- } \\
\text { flaps, in } 20 \text { patients) }\end{array}$ & $\begin{array}{l}\text { Pedicle was harvested with robot-assisted technique } \\
\text { Microvascular anastomosis via standard technique } \\
\text { An average pedicle length of } 6.7 \mathrm{~cm} \text { is long enough to allow } \\
\text { anastomosis without vein graft }\end{array}$ \\
\hline Van der Hulst et al. (22) & 2006 & Case report & $\begin{array}{l}\text { Breast reconstruction with muscle- } \\
\text { sparing free TRAM-flap, using robotic } \\
\text { arterial anastomosis }(N=1)\end{array}$ & $\begin{array}{l}\text { The time to perform this anastomosis was about } 40 \text { min and } \\
\text { significantly longer than the standard technique (around } 15 \text { min) }\end{array}$ \\
\hline
\end{tabular}

The number of procedures carried out in each study is documented and represented as $N$ number. 
TABLE 2 | Preclinical and clinical studies relating to the use of robotics in muscle flap harvest.

\begin{tabular}{|c|c|c|c|c|}
\hline Reference & Year & Study design & Operations performed & Outcomes reported \\
\hline \multicolumn{5}{|c|}{ Preclinical studies } \\
\hline Selber (25) & 2011 & Human cadaver & $\begin{array}{l}\text { Latissimus dorsi muscle harvest ( } N=10 \text { in } 8 \\
\text { cadavers) }\end{array}$ & Successful harvest of all muscles \\
\hline $\begin{array}{l}\text { Patel and } \\
\text { Pedersen (26) }\end{array}$ & 2012 & Human cadaver & $\begin{array}{l}\text { Rectus abdominis muscle dissection and harvest } \\
(N=2)\end{array}$ & No postoperative complications or surgical-site morbidity \\
\hline Selber et al. (27) & 2012 & Human cadaver & Latissimus dorsi muscle harvest and transfer $(N=8)$ & $\begin{array}{l}\text { Successful harvest and transfer of all flaps that left no visible } \\
\text { incisions, with no major complications }\end{array}$ \\
\hline \multicolumn{5}{|l|}{ Clinical studies } \\
\hline Patel et al. (28) & 2012 & Case report & $\begin{array}{l}\text { Pedicled myocutaneous latissimus dorsi flap for } \\
\text { shoulder reconstruction after sarcoma resection } \\
(N=1)\end{array}$ & $\begin{array}{l}\text { No objective outcomes reported-flap successfully raised } \\
\text { robotically } \\
\text { One of the limitations is the time/learning curve }\end{array}$ \\
\hline Lazzaro et al. (29) & 2013 & Case report & $\begin{array}{l}\text { Intercostal muscle flap after lobectomy (done in } \\
\text { conjunction with VATS) }(N=1)\end{array}$ & $\begin{array}{l}\text { Success of surgery - no conversion to open procedures and } \\
\text { both patients returned home } 5 \text { days postop }\end{array}$ \\
\hline Ibrahim et al. (30) & 2014 & Case series & $\begin{array}{l}\text { Rectus abdominus muscle flap harvest ( } N \text { not } \\
\text { reported) }\end{array}$ & $\begin{array}{l}\text { Less tissue violation, compared to open technique, resulting in } \\
\text { reduced postoperative pain, shorter duration of hospital stay, } \\
\text { and more rapid functional recovery }\end{array}$ \\
\hline Chung et al. (31) & 2015 & Case series & $\begin{array}{l}\text { Transaxillary gasless robot-assisted latissimus } \\
\text { dorsi muscle harvest ( } 3 \text { delayed reconstructions, } \\
4 \text { immediate after nipple sparing mastectomy, } \\
5 \text { corrections of deformity in Poland syndrome) } \\
(N=12)\end{array}$ & $\begin{array}{l}\text { Operating time, general satisfaction, cosmetic satisfaction, } \\
\text { scar, and symmetry satisfaction were all outcomes measured } \\
\text { via survey given to all patients with follow-up longer } \\
\text { than months } \\
\text { Robotic time decreases with experience }\end{array}$ \\
\hline Singh et al. (32) & 2015 & $\begin{array}{l}\text { Case series and } \\
\text { retrospective } \\
\text { review }\end{array}$ & $\begin{array}{l}\text { Extralevator abdominoperineal excision with robotic } \\
\text { rectus abdominis flap harvest, for reconstruction } \\
\text { after resection of distal rectal adenocarcinoma } \\
(N=3)\end{array}$ & $\begin{array}{l}\text { An incisionless robotic flap harvest with preservation of the } \\
\text { anterior rectus sheath obviates the risk of ventral hernia while } \\
\text { providing robust tissue closure of the radiated abdominoperineal } \\
\text { excision wound }\end{array}$ \\
\hline
\end{tabular}

The number of procedures carried out in each study is documented and represented as $N$ number.

cavity and oropharynx avoiding more traditional jaw and lip split approaches, facilitated by the improved access and visualization afforded by the robotic instruments $(51,52)$. If there is no communication between the oral cavity or oropharynx and neck dissection then the defect could be left to heal by secondary intention; however, in more complex or advanced stages of disease, reconstruction using local flaps or free tissue transfer is required (53). If a jaw split has not been performed, access for satisfactory reconstruction can be almost impossible and thus developing reconstructive techniques using the robot in order to capitalize on the minimized morbidity associated with a TORS resection is of paramount importance.

Trans-oral robotic surgery has become the biggest area for robotic-assisted plastic surgery procedures, with 2 preclinical $(54,55)$ and 21 clinical studies identified (56-76) (Table 5). Local reconstructive options include the use of the Facial Artery Musculomucosal flap, commonly used in reconstruction of the floor of the mouth and soft palate. Bonawitz and Duvvuri have described using the robot for raising and in-setting the flap with good results $(64,65)$. Others demonstrated that the use of the robot to perform a musculomucosal advancement flap pharyngoplasty gives good results, both in terms of orocutaneous fistula risk and functional outcomes $(60,61)$.

In larger or more complex composite defects there is often the requirement for free-flap reconstruction, with specific indications including exposure of the carotid artery, large baseof-tongue defects and defects of the soft palate and tonsillar fossa which cannot be closed with local flap options. The commonest reported free-flap used following TORS resection is the radial forearm flap; however, others such as the anterolateral thigh flap are also described. In the majority of cases the robot was used for flap inset, with authors reporting good access and visualization that allowed a water-tight inset to be achieved and no flap complications despite the lack of a traditional jaw spilled. The robot was also used in a number of studies to perform the vascular anastomosis $(58,62,63,69)$.

\section{Trans-Oral Robotic Cleft Surgery (TORCS)}

Trans-oral robotic cleft surgery is still in its infancy with only three articles identified (77-79) (Table 6); however, it builds upon the same benefit profile achieved by TORS that has been outlined previously for access to the oral cavity and oropharynx in cleft lip and palate patients.

\section{Other Indications}

Table 7 demonstrates four other studies identified in the systematic review, which do not fit into the categories above (80-83). Of these indications, it is likely that only lymph node based procedures are likely to progress in the future, with some benefits such as the ability to perform supermicro-surgery an obvious advantage in lymph node transfer. 
TABLE 3 | Preclinical and clinical studies relating to the use of robotics in nerve surgery.

\begin{tabular}{|c|c|c|c|c|}
\hline Reference & Year & Study design & Operations performed & Outcomes reported \\
\hline \multicolumn{5}{|l|}{ Preclinical studies } \\
\hline Latif et al. (34) & 2008 & Animal model & $\begin{array}{l}\text { Intercostal nerve grafting for reversal of thoracic } \\
\text { sympathectomy }(N=1)\end{array}$ & Successful anastomosis with no apparent complications \\
\hline Nectoux et al. (35) & 2009 & $\begin{array}{l}\text { Animal and human } \\
\text { tissue samples }\end{array}$ & $\begin{array}{l}\text { Extrafascicular neurolysis, donor nerve dissection } \\
\text { and subsequent repair of peripheral nerve ( } N \text { not } \\
\text { reported) }\end{array}$ & $\begin{array}{l}\text { The robot removed physiological tremor } \\
\text { There was some technical difficulty with the choice and } \\
\text { manipulation of the three-dimensional stereoscopic vision } \\
\text { enabled a better view and safe and accurate repair of } \\
\text { peripheral nerve lesions }\end{array}$ \\
\hline Mantovani et al. (36) & 2011 & Human cadaver & $\begin{array}{l}\text { Supraclavicular brachial plexus exploration and } \\
\text { nerve graft anastomosis and reconstruction } \\
(N=2)\end{array}$ & $\begin{array}{l}\text { The robot allowed microsurgery to be performed in a very } \\
\text { small space with telemanipulation and minimally invasive } \\
\text { techniques }\end{array}$ \\
\hline Garcia et al. (37) & 2012 & Human cadaver & $\begin{array}{l}\text { Sural nerve graft and neurotisation using the } \\
\text { accessory nerve }(N=3)\end{array}$ & $\begin{array}{l}\text { The goals of the operation were achieved without } \\
\text { conversion to open surgery. There were no complications }\end{array}$ \\
\hline de Melo et al. (38) & 2013 & Human cadaver & $\begin{array}{l}\text { Microsurgical nerve transfer of the branches of the } \\
\text { axillary nerve onto the nerve of the long head of } \\
\text { the triceps brachii }(N=1)\end{array}$ & Dissection and transfer achieved successfully \\
\hline Facca et al. (39) & 2014 & Human cadaver & $\begin{array}{l}\text { Sural nerge graft between C5 root or spinal nerve, } \\
\text { and the musculocutaneous nerve }(N=8)\end{array}$ & $\begin{array}{l}\text { Endoscopic treatment of supraclavicular nerve palsy } \\
\text { is feasible, however, both sural nerve grafts and C5-6 } \\
\text { avulsions were converted to open }\end{array}$ \\
\hline Porto de Melo et al. (40) & 2014 & Animal model & $\begin{array}{l}\text { Phrenic nerve harvest and application in brachial } \\
\text { plexus surgery }(N=1)\end{array}$ & Successful nerve harvest \\
\hline Miyamoto et al. (41) & 2016 & Animal model & $\begin{array}{l}\text { Intercostal nerve harvest for brachial plexus } \\
\text { reconstruction }(N=3)\end{array}$ & $\begin{array}{l}\text { Physiological tremor was eliminated and there were no } \\
\text { major complications }\end{array}$ \\
\hline \multicolumn{5}{|l|}{ Clinical studies } \\
\hline Latif et al. (42) & 2011 & Case study & $\begin{array}{l}\text { Intercostal nerve graft harvesting and grafting } \\
\text { into sympathetic chain using tension free nerve } \\
\text { anastomoses }(N=1)\end{array}$ & $\begin{array}{l}\text { Successful operation, patient discharged one day } \\
\text { postoperatively and no sign of Horner's syndrome on } \\
\text { short term follow-up }\end{array}$ \\
\hline Coveliers et al. (43) & 2013 & $\begin{array}{l}\text { Case cohort, } \\
\text { retrospective }\end{array}$ & $\begin{array}{l}\text { Selective postganglionic thoracic sympathectomy } \\
\text { for patients with palmar or axillary hyperhidrosis } \\
\text { ( } N=110 \text { operations in } 55 \text { patients) }\end{array}$ & $\begin{array}{l}\text { Of the } 55 \text { patients, } 53 \text { ( } 96 \% \text { ) had sustained relief of their } \\
\text { hyperhidrosis at a median follow-up of } 24 \text { months (range, } \\
3 \text { to } 36 \text { months), and compensatory sweating was seen } \\
\text { in four patients }(7.2 \%)\end{array}$ \\
\hline Naito et al. (44) & 2012 & Case cohort & $\begin{array}{l}\text { The Oberlin procedure of nerve transfer for } \\
\text { restoration of elbow flexion }(N=4)\end{array}$ & $\begin{array}{l}\text { At } 12 \text { months' mean follow-up, all patients had recovered } \\
\text { to useful elbow flexion, with no sensory/motor deficit in } \\
\text { the ulnar nerve territory }\end{array}$ \\
\hline Berner (45) (book chapter) & 2013 & Case series & Repair of brachial plexus injury $(N=12)$ & $\begin{array}{l}\text { Considering the microsurgical gesture, all nerve repairs } \\
\text { were achieved under excellent conditions } \\
\text { Need to convert to open surgery in nine cases }\end{array}$ \\
\hline Tigan et al. (46) & 2014 & Case cohort & $\begin{array}{l}\text { Nerve grafting after excision of benign peripheral } \\
\text { nerve tumors }(N=7)\end{array}$ & $\begin{array}{l}\text { In postoperative surveys, neuropathic pain halved } \\
\text { from } 6 / 10 \text { to } 3 / 10 \text { postop, with no worsening of } \\
\text { sensory deficits }\end{array}$ \\
\hline
\end{tabular}

The number of procedures carried out in each study is documented and represented as $N$ number.

\section{DISCUSSION}

In the 30 years since the first robot was used in a surgical procedure the arena of robotic surgery has changed at a breathtaking pace, with the use of the $\mathrm{daVinci}^{\circledR}$ robot now common place in some specialties. This revolution has taken longer to impact on the plastic surgery community. It is, therefore, somewhat ironic that it was a plastic surgeon who was at the forefront of robotic and tele-surgery at its inception (84). However, this systematic review has shown that significant developments have been made in the last few years.

The benefits of robotic surgery have been well documented, albeit with no large scale studies, and include reduced blood loss, reduced postoperative pain, faster recovery, and improved cosmesis (85). In relation to plastic and reconstructive surgery the elimination of tremor, greater degree of freedom of the instrument and motion scaling all have the potential to improve the accuracy and reproducibility of microsurgery. The evidence suggests that while the initial learning curve is steep, proficiency in microsurgical skills using the robot can be gained in a short number of sessions (18).

Of the areas identified in this systematic review there are some that are further down the development road than others and some, where the advantages of robotic assistance are greater. For example, with the recent uptake of free-perforator flaps in the field of reconstructive surgery we are beginning to approach the limits of human dexterity at which point the robot may prove to 
TABLE 4 | Preclinical and clinical studies relating to the use of robotics in upper limb procedures.

\begin{tabular}{|c|c|c|c|c|}
\hline Reference & Year & Study design & Operations performed & Outcomes reported \\
\hline \multicolumn{5}{|c|}{ Preclinical studies } \\
\hline Taleb et al. (47) & 2009 & Animal cadaver & $\begin{array}{l}\text { Humeral cross-section, amputation, and replantation of } \\
\text { the left forelimb. Stages done with surgical robot were } \\
\text { soft tissue repair and vessel patency tests during limb } \\
\text { replantation (not any microvascular procedures) }(N=1)\end{array}$ & $\begin{array}{l}\text { Patency tests were all positive. Venous bleeding } \\
\text { demonstrated vascular success of replantation } \\
\text { The robot removed physiological tremor and allowed for a } \\
\text { smaller operating field }\end{array}$ \\
\hline Huart et al. (48) & 2012 & $\begin{array}{l}\text { Human } \\
\text { cadaver }\end{array}$ & Kite flap hand surgery $(N=1)$ & $\begin{array}{l}\text { Operating time was longer with the robot, but kite flap } \\
\text { transfer was successful }\end{array}$ \\
\hline Maire et al. (49) & 2012 & $\begin{array}{l}\text { Human } \\
\text { cadaver }\end{array}$ & $\begin{array}{l}\text { Removal of left hallux medial hemipulp (with sensory nerve, } \\
\text { collateral artery and dorsal vein) and transfer to left thumb } \\
\text { radial hemipulp }(N=1)\end{array}$ & $\begin{array}{l}\text { Successful free hallux hemipulp transfer, however, } \\
\text { operating time was increased by non-microsurgical } \\
\text { moments which could be improved by instrumentation } \\
\text { improvement }\end{array}$ \\
\hline \multicolumn{5}{|l|}{ Clinical studies } \\
\hline $\begin{array}{l}\text { Facca and } \\
\text { Liverneaux (50) }\end{array}$ & 2010 & Case report & $\begin{array}{l}\text { Robotic anastomosis of vein grafts for hypothenar hammer } \\
\text { syndrome }(N=1)\end{array}$ & $\begin{array}{l}\text { No postoperative problems of note } \\
\text { Successful cure of vasomotor disorder }\end{array}$ \\
\hline
\end{tabular}

The number of procedures carried out in each study is documented and represented as N number.

TABLE 5 | Preclinical and clinical studies relating to the use of robotics in trans-oral robotic surgery (TORS) for a plastic surgery application.

\begin{tabular}{lllll}
\hline Reference & Year & Study design & Operations performed & Outcomes reported \\
\hline Preclinical studies & & & & \\
\hline Selber et al. (54) & 2010 & $\begin{array}{l}\text { Coffee cup models, } \\
\text { pig cadavers, human } \\
\text { cadavers }\end{array}$ & $\begin{array}{l}\text { TORS free radial forearm flap reconstruction of } \\
\text { oropharyngeal defect }(N=2) \\
\text { Robotic microvascular anastomosis }\end{array}$ & $\begin{array}{l}\text { Successful reconstruction of the oropharynx by trans- } \\
\text { oral robotic flap inset and microvascular anastomosis }\end{array}$ \\
\hline Smartt et al. (55) & 2013 & Human cadaver & $\begin{array}{l}\text { Superiorly based posterior pharyngeal flap } \\
\text { transfer }(N=3)\end{array}$ & $\begin{array}{l}\text { Successful transfer of posterior pharyngeal flaps, with } \\
\text { mean surgical time of } 113 \text { min. Technically, the learning } \\
\text { curve for using the robot telemanipulator was steep } \\
\end{array}$ \\
& & & & There was no damage to adjacent structures
\end{tabular}

\section{Clinical studies}

\begin{tabular}{|c|c|c|c|c|}
\hline Desai et al. (56) & 2008 & $\begin{array}{l}\text { Case cohort, } \\
\text { retrospective analysis }\end{array}$ & $\begin{array}{l}\text { Mucosal flap and pyriform sinus flap } \\
\text { reconstructions }(N=7)\end{array}$ & $\begin{array}{l}\text { No intra- or postoperative complications, one patient } \\
\text { required tracheostomy }\end{array}$ \\
\hline Mukhija et al. (57) & 2009 & Case series & $\begin{array}{l}\text { Radial forearm fasciocutaneous free-flap harvest } \\
\text { and reconstruction of oral cavity }(N=2)\end{array}$ & $\begin{array}{l}\text { Successful positioning of the flap, shorter operating } \\
\text { time compared to conventional techniques, shorter } \\
\text { hospital stay compared to mandibulotomy approach }\end{array}$ \\
\hline Selber (58) & 2010 & Case series & $\begin{array}{l}\text { Free-flap reconstruction of oropharynx (radial } \\
\text { forearm free-flap, anterolateral thigh flap, } \\
\text { facial artery, myomucosal flap), primary closure } \\
\text { after tumor resection, and microvascular } \\
\text { anastomosis }(N=5)\end{array}$ & $\begin{array}{l}\text { Better access and improved precision within the } \\
\text { oropharynx, compared to conventional tecnhiques } \\
\text { Successful microvascular anastomosis }\end{array}$ \\
\hline Garfein et al. (59) & 2011 & Case report & $\begin{array}{l}\text { Radial forearm flap for reconstruction of the } \\
\text { tounge base, vallecula and pre-epiglotic space, } \\
\text { due to soft tissue and hyoid radionecrosis } \\
(N=1)\end{array}$ & $\begin{array}{l}\text { The patient passed a swallow evaluation after } 1 \text { week, } \\
\text { and started an oral diet } 8 \text { days after the operation } \\
\text { There was good function showed by video } \\
\text { oesophagram } 6 \text { week postoperatively }\end{array}$ \\
\hline \multirow[t]{2}{*}{ Genden et al. (60) } & \multirow[t]{2}{*}{2011} & \multirow[t]{2}{*}{$\begin{array}{l}\text { Prospective non- } \\
\text { randomized case- } \\
\text { control study }\end{array}$} & \multirow[t]{2}{*}{$\begin{array}{l}\text { Free-flap reconstruction of oropharynx- } \\
\text { sternocleidomastoid free-flap, mucosal } \\
\text { mulscular flaps and pharyngoplasty }(N=30)\end{array}$} & $\begin{array}{l}\text { Equivalent rates of loco-regional and distant control } \\
\text { of malignancy and better short-term eating ability, } \\
\text { compared to conventional techniques }\end{array}$ \\
\hline & & & & No major long term sequelae \\
\hline Genden et al. (61) & 2011 & $\begin{array}{l}\text { Prospective non- } \\
\text { randomized case- } \\
\text { control study }\end{array}$ & $\begin{array}{l}\text { Musculomucosal advancement flap } \\
\text { pharyngoplasty }(N=30) \\
\text { Radial forearm free-flap reconstruction }\end{array}$ & $\begin{array}{l}\text { Postoperatively, patients regained excellent function, } \\
\text { with near-normal scores on the Functional Oral } \\
\text { Intake Scale and Performance Status Scale for Head } \\
\text { and Neck Cancer Patients at } 1 \text { year after surgery }\end{array}$ \\
\hline Bonawitz and Duvvuri (62) & 2012 & $\begin{array}{l}\text { Case cohort, } \\
\text { retrospective }\end{array}$ & $\begin{array}{l}\text { Free-flap oropharyngeal reconstruction, with } \\
\text { microvascular anastomoses in the tongue base } \\
\text { and soft palate ( } N \text { not reported) }\end{array}$ & No major complications and no flap loss \\
\hline
\end{tabular}


TABLE 5 | Continued

\begin{tabular}{|c|c|c|c|c|}
\hline Reference & Year & Study design & Operations performed & Outcomes reported \\
\hline Longfield et al. (63) & 2012 & Case series & $\begin{array}{l}\text { Robotic reconstruction after resection squamous } \\
\text { cell carcinoma of the oropharynx using local } \\
\text { and distant free-flaps, with microvascular } \\
\text { anastomoses ( } N \text { not reported) }\end{array}$ & $\begin{array}{l}\text { Patients can be safely reconstructed (locally or with free } \\
\text { tissue transfer) robotically after TORS }\end{array}$ \\
\hline Bonawitz and Duvvuri (64) & 2013 & Case series & $\begin{array}{l}\text { Local random transposition flaps from buccal } \\
\text { mucosa, the hard palate or the pharyngeal wall } \\
\text { ( } N \text { not reported) } \\
\text { Facial artery musculomucosal (FAMM) flap for } \\
\text { larger defects of the soft palate }\end{array}$ & No major complications \\
\hline Bonawitz and Duvvuri (65) & 2013 & $\begin{array}{l}\text { Case cohort, } \\
\text { retrospective }\end{array}$ & $\begin{array}{l}\text { FAMM flap reconstruction after removal of } \\
\text { malignant tumors of the soft palate }(N=5)\end{array}$ & No major complications, no flap loss \\
\hline Duvvuri et al. (66) & 2013 & $\begin{array}{l}\text { Case cohort, } \\
\text { retrospective }\end{array}$ & $\begin{array}{l}\text { Oropharyngeal reconstruction with FAMM free- } \\
\text { flaps, ALT free-flaps, radial forearm flaps and } \\
\text { uvular flaps }(N=12)\end{array}$ & $\begin{array}{l}\text { No major complications, some minor flap dehiscence, } \\
\text { two revision procedures needed (one fistula, one bulky } \\
\text { flap) }\end{array}$ \\
\hline Hans et al. (67) & 2013 & Case series & $\begin{array}{l}\text { Radial forearm free-flap reconstruction after } \\
\text { resection of hypopharyngeal carcinoma }(N=2)\end{array}$ & $\begin{array}{l}\text { A complication of a neck hematoma requiring draining } \\
\text { under general anesthesia, no fistulae }\end{array}$ \\
\hline Park et al. (68) & 2013 & $\begin{array}{l}\text { Case series, } \\
\text { prospective study }\end{array}$ & $\begin{array}{l}\text { Radial forearm muscle free-flap reconstruction of } \\
\text { oropharynx }(N=7)\end{array}$ & $\begin{array}{l}\text { No surgery-related complications of infections, } \\
\text { viable and functioning free-flaps in all patients, one } \\
\text { hundred percent of patients happy with postoperative } \\
\text { appearance and could tolerate an oral diet }\end{array}$ \\
\hline Song et al. (69) & 2013 & Case series & $\begin{array}{l}\text { Robotic ablation surgery, free-flap reconstruction } \\
\text { (radial forearm free-flaps, anterolateral thigh flap), } \\
\text { and microvascular anastomosis }(N=5)\end{array}$ & $\begin{array}{l}\text { Flap insetting and microanastomoses were achieved } \\
\text { using a specially manufactured robotic instrument } \\
\text { No complications }\end{array}$ \\
\hline De Almeida et al. (70) & 2014 & $\begin{array}{l}\text { Case cohort, } \\
\text { retrospective }\end{array}$ & $\begin{array}{l}\text { Velopharyngoplasty reconstructinos with } \\
\text { local flaps alone, regional and free-flaps, and } \\
\text { secondary healing }(N=92)\end{array}$ & Good swallowing outcomes, no carotid artery ruptures \\
\hline Byeon et al. (71) & 2015 & Case series & $\begin{array}{l}\text { Reconstruction and lymph node dissection for } \\
\text { head and neck malignancy }(N=37)\end{array}$ & Good cosmetic outcomes and no major complications \\
\hline \multirow[t]{4}{*}{ Perrenot et al. (72) } & \multirow[t]{4}{*}{2014} & \multirow[t]{4}{*}{ Case series } & \multirow{4}{*}{$\begin{array}{l}\text { Infra-hyoid myocutaneous flap reconstructions } \\
(N=8)\end{array}$} & Good esthetic results \\
\hline & & & & One case required re-operating due to hemostasis \\
\hline & & & & No other complications \\
\hline & & & & $\begin{array}{l}\text { Seven out of eight patients tolerated oral feeding } \\
\text { postoperatively }\end{array}$ \\
\hline Lai et al. (73) & 2015 & Case cohort & $\begin{array}{l}\text { Free radial forearm fasciocutaneous flap } \\
\text { reconstruction after resection of oropharyngeal } \\
\text { cancer }(N=5)\end{array}$ & $\begin{array}{l}\text { All reconstructive surgeries were successful, with no } \\
\text { flap failure or take-backs, no wound infections and no } \\
\text { fistulae }\end{array}$ \\
\hline Meccariello et al. (74) & 2016 & Case report & $\begin{array}{l}\text { Resection and reconstruction, with temporalis } \\
\text { muscle flap, of squamous cell carcinoma of the } \\
\text { lateral oropharyngeal wall extending into the soft } \\
\text { palate }(N=1)\end{array}$ & $\begin{array}{l}\text { Restoration of a competent velopharyngeal sphincter, } \\
\text { with water-tight seal between pharynx and neck } \\
\text { Timely healing and enhanced postoperative functional } \\
\text { results }\end{array}$ \\
\hline Gorphe et al. (75) & 2017 & $\begin{array}{l}\text { Non-randomized } \\
\text { phase II muti-center } \\
\text { prospective trial }\end{array}$ & $\begin{array}{l}\text { FAMM and free ALT flap reconstructions of the } \\
\text { oropharynx }(N=9)\end{array}$ & $\begin{array}{l}\text { Robotic surgery proved feasible, and further } \\
\text { technological progress in developing robotic systems } \\
\text { specifically for trans-oral surgery will be of benefit to } \\
\text { patients }\end{array}$ \\
\hline Biron et al. (76) & 2017 & Case-control series & $\begin{array}{l}\text { Radial forearm free-flap reconstruction after } \\
\text { excision of oropharyngeal squamous cell } \\
\text { carcinoma }(N=18)\end{array}$ & $\begin{array}{l}\text { Significantly shorter admission duration and fewer } \\
\text { postoperative complications }\end{array}$ \\
\hline
\end{tabular}

The number of procedures carried out in each study is documented and represented as $N$ number.

be advantageous. However, to fully exploit this there needs to be focused development in the field of robotic instrument design, expanding the portfolio of micro-instruments. It is our opinion that the potential for robotic head and neck reconstruction is huge and is one of the areas that will most definitely see growth due to the obvious benefits it offers. This will be especially true as the indications for TORS resection continue to widen, resulting in larger and more complex defects. The current limitation to more widespread utilization is instrument design in order to perform microvascular anastomoses and easier inset and it is 
TABLE 6 | Preclinical and clinical studies relating to the use of robotics in trans-oral robotic cleft surgery.

\begin{tabular}{|c|c|c|c|c|}
\hline Reference & Year & Study design & Operations performed & Outcomes reported \\
\hline \multicolumn{5}{|l|}{ Preclinical studies } \\
\hline Khan et al. (77) & 2016 & $\begin{array}{l}\text { Airway manikin and } \\
\text { human cadaver }\end{array}$ & $\begin{array}{l}\text { The Hynes pharyngoplasty } \\
(N=1)\end{array}$ & $\begin{array}{l}\text { With each variation, a subjective assessment (rated as poor, fair, good or } \\
\text { excellent) was made for vision and access to either the posterior pharynx or } \\
\text { palate, and it was validated by two of the authors for each set-up }\end{array}$ \\
\hline Podolsky et al. (78) & 2017 & $\begin{array}{l}\text { Cleft palate } \\
\text { simulator test bed }\end{array}$ & $\begin{array}{l}\text { The von Langenbeck cleft } \\
\text { palate repair procedure }(N=1)\end{array}$ & $\begin{array}{l}\text { Excellent close up visualization of the anatomy, the ability to articulate the wrist } \\
\text { intra-orally (not possible with standard instruments), tremor reduction, better } \\
\text { ambidexterity and more precise dissection and tissue manipulation, compared to } \\
\text { conventional open techniques }\end{array}$ \\
\hline \multicolumn{5}{|l|}{ Clinical studies } \\
\hline Nadjmi (79) & 2015 & $\begin{array}{l}\text { Controlled cohort } \\
\text { study }\end{array}$ & $\begin{array}{l}\text { The robot was used to } \\
\text { dissection and repair the } \\
\text { palatine muscles in } 10 \text { patients } \\
\text { with a cleft of the palate } \\
\text { ( } N=10,30 \text { controls) }\end{array}$ & $\begin{array}{l}\text { Increased dexterity and operative view using the robot } \\
\text { Overall operative time was longer using the robot compared to the control group in } \\
\text { which the traditional method was used }\end{array}$ \\
\hline
\end{tabular}

The number of procedures carried out in each study is documented and represented as $N$ number.

TABLE 7 | Preclinical and clinical studies relating to the use of robotics in other, miscellaneous areas of plastic and reconstructive surgery.

\begin{tabular}{|c|c|c|c|c|}
\hline Reference & Year & Study design & Operations performed & Outcomes reported \\
\hline \multicolumn{5}{|c|}{ Microvascular surgery } \\
\hline Dombre et al. (80) & 2003 & Live animal model & Skin graft ( $N$ not reported) & $\begin{array}{l}\text { Robotically harvested skin samples were of the same quality } \\
\text { as manually harvested ones }\end{array}$ \\
\hline Taghizadeh et al. (81) & 2014 & Human cadaver & $\begin{array}{l}\text { "Necklift" platysmaplasty-a short incision facelift } \\
\text { with concomitant robot-assisted neck lift }(N=6)\end{array}$ & $\begin{array}{l}\text { Successful necklift procedures, with certain areas for } \\
\text { improvement in surgical methodology suggested when using } \\
\text { robotic systems (hard to interpret) }\end{array}$ \\
\hline Shi et al. (82) & 2017 & Live animal model & Mandibular bone drilling osteotomy $(N=1)$ & $\begin{array}{l}\text { The robotically assisted drilling demonstrated more accurate } \\
\text { drill positioning, increased stability and accuracy, and relieved } \\
\text { surgeon fatigue so as to reduce facial trauma }\end{array}$ \\
\hline \multicolumn{5}{|l|}{ Clinical studies } \\
\hline \multirow[t]{2}{*}{ Ciudad et al. (83) } & 2016 & Case-report & $\begin{array}{l}\text { Tight gastroepiploic lymph node flap (RGE-LNF) } \\
\text { for the treatment of lymphedema of the extremities } \\
(N=1)\end{array}$ & $\begin{array}{l}\text { Successful flap harvest, but no postoperative surgical } \\
\text { outcomes reported }\end{array}$ \\
\hline & & & $\begin{array}{l}\text { Microvascular procedures performed with standard } \\
\text { technique }\end{array}$ & \\
\hline
\end{tabular}

The number of procedures carried out in each study is documented and represented as $\mathrm{N}$ number.

this area that research should focus. This may also be the case with TORCS. As with cancer resection, there are many circumstances where adequate access to the pharynx and palate in the pediatric cleft patient can pose a significant challenge. The space in which to operate, as well as access for instrumentation, can be severely restricted, especially in cases with abnormal anatomy, poor jaw opening, or anomalies of the nasopharyngeal space. Adequate illumination and visualization can also be difficult. Early work has shown that performing posterior pharyngeal wall surgery using the daVinci ${ }^{\circledR}$ robot is feasible, with benefits such as an improved view, easier dissection, reduced secondary surgical insult and preferential ergonomics for the operating surgeon (77). Its use may also open up avenues of new surgical interventions to areas of the oropharynx that were previously inaccessible.

There is currently less convincing evidence for the use of robotics in areas such as nerve and upper limb surgery. In brachial plexus reconstruction nerve harvest is often required and, therefore, reduced donor site morbidity through robotic harvest, such as with trans-thoracic harvest of intercostal and phrenic nerves, is an area that has the potential for future advancement. It will be important, however, to also demonstrate its safety and cost-effectiveness in order to justify the marginal reductions in scarring when compared to more traditional harvest sites. To date all of the preclinical and clinical studies investigating robotic nerve surgery have demonstrated that it is technically feasible. However, it is still mostly at a proof of concept level and while does have benefits in terms of reduced tremor, it is most likely to be of benefit in difficult to assess areas or when the robot is already being used to perform other parts of the procedure. Finally, at present the indications for the use of robotics in hand surgery are probably more limited than other areas discussed, especially as access is not normally a problem in hand surgery. However, the benefits as discussed for microsurgical anastomosis may prove to 
be useful in specific indications such as traumatic replantation or congenital reconstruction.

Robotic surgery's main disadvantage remains the high cost of purchasing and maintaining the equipment. This will undoubtedly improve with time as a greater number of procedures are performed using the robot and the unit cost per operation reduces. A recent comparison of the cost of TORS compared to radiotherapy demonstrated that TORS is currently more expensive; however, this is likely to reduce through the creation of high-volume centers performing TORS (86). It has also been shown that in a center where the learning curve had already been overcome, robotic surgery was cheaper than equivalent open surgery for the surgical treatment of endometrial cancer (87).

Lack of haptic feedback is also often cited as another disadvantage of robotic surgery, with studies demonstrating that operators of augmented robotic surgical systems prefer those with haptic feedback (88). However, other studies such as by Hagen and colleagues who looked at 52 individuals and their perception of haptic feedback while performing robotic surgery demonstrated that visual cues are able to give the perception of haptic feedback, even when true haptic feedback is not present (89). Despite this evidence there is still a tremendous amount of working looking at ways to incorporate haptic feedback into robotic systems, summarized in a review by Okamura (90).

Finally, robotic surgery often results in longer operative times, although this improves with proficiency and in some cases is now comparable to traditional techniques.

The future of robotics in plastic surgery is clearly exciting. Over the last 5 years the range of procedures using the $\mathrm{daVinci}^{\circledR}$ robot being attempted by the plastic surgery community has increased significantly and, as technology continues to improve, this will gain further momentum. Of the 68 studies included in this review, only three used a robotic system other than the $\mathrm{daVinci}^{\circledR}$. This dominance is beginning to be challenged and while equipment additions such as a micro-forcep is currently available for the daVinci ${ }^{\circledR}$ robot and external companies have developed

\section{REFERENCES}

1. Ballantyne GH. Robotic surgery, telerobotic surgery, telepresence, and telementoring. Review of early clinical results. Surg Endosc (2002) 16(10):1389-402. doi:10.1007/s00464-001-8283-7

2. Kappert U, Cichon R, Schneider J, Gulielmos V, Tugtekin SM, Matschke K, et al. Robotic coronary artery surgery - the evolution of a new minimally invasive approach in coronary artery surgery. Thorac Cardiovasc Surg (2000) 48(4):193-7. doi:10.1055/s-2000-6904

3. Ishikawa N, Watanabe G, Iino K, Tomita S, Yamaguchi S, Higashidani K, et al. Robotic internal thoracic artery harvesting. Surg Today (2007) 37(11):944-6. doi:10.1007/s00595-007-3542-4

4. Cadière GB, Himpens J, Germay O, Izizaw R, Degueldre M, Vandromme J, et al. Feasibility of robotic laparoscopic surgery: 146 cases. World J Surg (2001) 25(11):1467-77. doi:10.1007/s00268-001-0132-2

5. Bush SH, Apte SM. Robotic-assisted surgery in gynecological oncology. Cancer Control (2015) 22(3):307-13. doi:10.1177/107327481502200308

6. Barbash GI, Glied SA. New technology and health care costs - the case of robot-assisted surgery. N Engl J Med (2010) 363(8):701-4. doi:10.1056/ NEJMp1006602

7. Pappou EP, Weiser MR. Robotic colonic resection. JSurg Oncol (2015) 112(3):315-20. doi:10.1002/jso.23953 micro-doppler probes and hydrojet dissectors (91) it will be the development of further microsurgical instruments that will allow greater use of the robot in the field of plastic and reconstructive surgery. The combination of motion scaling and tremor-free instrument manipulation with new instrument design will also allow new avenues in microsurgery that have to date been too technically demanding to be explored. Furthermore, the introduction of a new single port addition to the daVinci ${ }^{\circledR}$ system will allow greater access in trans-oral surgery, improving instrument maneuverability within the tight confines of the intra-oral cavity.

\section{CONCLUSION}

The potential value of robotic plastic surgery has already been investigated in several specific indications. It is still early days for the field and only time will tell if the use of robotics in plastic surgery is truly of benefit. As the technology, knowledge, and skills in this area improve, it is likely that in specific indications the use of robotic surgery will further contribute positively to patient and provider experience and outcomes. It is, therefore, imperative that the plastic surgery community embraces this new technology platform, but in doing so conducts well-designed, patient-focused research to ensure that it is only being used when there is true benefit to our patients.

\section{AUTHOR CONTRIBUTIONS}

TD, KK, and IW developed the idea for this paper. TD, OC, and HS developed the search strategy and performed the systematic review and data extraction. TD, KK, IW, OC, and HS wrote the manuscript and all authors edited and agreed the final version.

\section{FUNDING}

This work has received no specific funding. TD is funded by the Welsh Clinical Academic Training Fellowship.
8. Moher D, Liberati A, Tetzlaff J, Altman DG. Preferred reporting items for systematic reviews and meta-analyses: the PRISMA statement. Ann Intern Med (2009) 151(4):264-9. doi:10.1016/j.jclinepi.2009.06.005

9. Higgins JPT, Green S, editors. Cochrane handbook for systematic reviews of interventions version 5.1.0 [updated March 2011]. The Cochrane Collaboration. (2011).

10. Katz RD, Rosson GD, Taylor JA, Singh NK. Robotics in microsurgery: use of a surgical robot to perform a free flap in a pig. Microsurgery (2005) 25:566-9. doi:10.1002/micr.20160

11. Knight CG, Lorincz A, Cao A, Gidell K, Klein MD, Langenburg SE. Computer-assisted, robot-enhanced open microsurgery in an animal model. J Laparoendosc Adv Surg Tech A (2005) 15(2):182-5. doi:10.1089/ lap.2005.15.182

12. Karamanoukian RL, Finley DS, Evans GR, Karamanoukian HL. Feasibility of robotic-assisted microvascular anastomoses in plastic surgery. J Reconstr Microsurg (2006) 22(06):429-32. doi:10.1055/s-2006-947697

13. Katz RD, Taylor JA, Rosson GD, Brown PR, Singh NK. Robotics in plastic and reconstructive surgery: use of a telemanipulator slave robot to perform microvascular anastomoses. J Reconstr Microsurg (2006) 22:53-7. doi:10.1055/s-2006-931908

14. Taleb C, Nectoux E, Liverneaux PA. Telemicrosurgery: a feasibility study in a rat model. Chir Main (2008) 27(2-3):104-8. doi:10.1016/j.main. 2008.04.001 
15. Ramdhian RM, Bednar M, Mantovani GR, Facca SA, Liverneaux PA. Microsurgery and telemicrosurgery training: a comparative study. J Reconstr Microsurg (2011) 27(09):537-42. doi:10.1055/s-0031-1285985

16. Lee JY, Mattar T, Parisi TJ, Carlsen BT, Bishop AT, Shin AY. Learning curve of robotic-assisted microvascular anastomosis in the rat. J Reconstr Microsurg (2012) 28(07):451-6. doi:10.1055/s-0031-1289166

17. Robert E, Facca S, Atik T, Bodin F, Bruant-Rodier C, Liverneaux P. Vascular microanastomosis through an endoscopic approach: feasibility study on two cadaver forearms. Chir Main (2013) 32(3):136-40. doi:10.1016/j.main. 2013.01.002

18. Alrasheed T, Liu J, Hanasono MM, Butler CE, Selber JC. Robotic microsurgery: validating an assessment tool and plotting the learning curve. Plast Reconstr Surg (2014) 134:794-803. doi:10.1097/PRS.0000000000000550

19. Selber JC, Alrasheed T. Robotic microsurgical training and evaluation. Semin Plast Surg (2014) 28(1):005-010. doi:10.1055/s-0034-1368161

20. Willems JI, Shin AM, Shin DM, Bishop AT, Shin AY. A comparison of robotically assisted microsurgery versus manual microsurgery in challenging situations. Plast Reconstr Surg (2016) 137(4):1317-24. doi:10.1097/PRS. 0000000000002030

21. Boyd B, Umansky J, Samson M, Boyd D, Stahl K. Robotic harvest of internal mammary vessels in breast reconstruction. J Reconstr Microsurg (2006) 22(4):261-6. doi:10.1055/s-2006-939931

22. van der Hulst R, Sawor J, Bouvy N. Microvascular anastomosis: is there a role for robotic surgery? J Plast Reconstr Aesthetic Surg (2007) 60(1):101-2. doi:10.1016/j.bjps.2006.05.011

23. Greensmith A, Januszkiewicz J, Poole G. Rectus abdominis muscle free flap by laparoscopic sheath-sparing technique. Plast Reconstr Surg (2000) 105(4):1438-41. doi:10.1097/00006534-200004040-00026

24. Aijaz T, Singhal D, Tan SA, Iqbal A. A novel method of minimally invasive rectus abdominis muscle flap harvest: laparoscopic surgeons take note. J Minim Access Surg (2017) 13(2):146-7. doi:10.4103/0972-9941.186688

25. Selber JC. Robotic latissimus dorsi muscle harvest. Plast Reconstr Surg (2011) 128(2):88.e-90.e. doi:10.1097/PRS.0b013e31821ef25d

26. Patel NV, Pedersen JC. Robotic harvest of the rectus abdominis muscle: a preclinical investigation and case report. J Reconstr Microsurg (2012) 28:477-80. doi:10.1055/s-0031-1287674

27. Selber JC, Baumann DP, Holsinger CF. Robotic harvest of the latissimus dorsi muscle: laboratory and clinical experience. J Reconstr Microsurg (2012) 28:457-64. doi:10.1055/s-0032-1315789

28. Patel NP, Van Meeteren J, Pedersen J. A new dimension: robotic reconstruction in plastic surgery. J Robot Surg (2012) 6(1):77-80. doi:10.1007/ s11701-011-0300-9

29. Lazzaro RS, Guerges M, Kadosh B, Gulkarov I. Robotic harvest of intercostal muscle flap. J Thorac Cardiovasc Surg (2013) 146(2):486-7. doi:10.1016/j.jtcvs. 2013.03.037

30. Ibrahim AE, Sarhane KA, Pederson JC, Selber JC. Robotic harvest of the rectus abdominis muscle: principles and clinical applications. Semin Plast Surg (2014) 28(1):26-31. doi:10.1055/s-0034-1368164

31. Chung JH, You HJ, Kim HS, Lee BI, Park SH, Yoon ES. A novel technique for robot assisted latissimus dorsi flap harvest. J Plast Reconstr Aesthet Surg (2015) 68:966-72. doi:10.1016/j.bjps.2015.03.021

32. Singh P, Teng E, Cannon LM, Bello BL, Song DH, Umanskiy K. Dynamic article: tandem robotic technique of extralevator abdominoperineal excision and rectus abdominis muscle harvest for immediate closure of the pelvic floor defect. Dis Colon Rectum (2015) 58(9):885-91. doi:10.1097/ DCR.0000000000000419

33. Lee SH, Lim S, Kim JH, Lee KY. Robotic versus conventional laparoscopic surgery for rectal cancer: systematic review and meta-analysis. Ann Surg Treat Res (2015) 89:190-201. doi:10.4174/astr.2015.89.4.190

34. Latif MJ, Afthinos JN, Connery CP, Perin N, Bhora FY, Chwajol M, et al. Robotic intercostal nerve graft for reversal of thoracic sympathectomy: a large animal feasibility model. Int J Med Robot (2008) 4(3):258-62. doi:10.1002/ rcs. 205

35. Nectoux E, Taleb C, Liverneaux P. Nerve repair in telemicrosurgery: an experimental study. J Reconstr Microsurg (2009) 25:261-5. doi:10.1055/ s-0028-1104562

36. Mantovani G, Liverneaux P, Garcia JC Jr, Berner SH, Bednar MS, Mohr CJ. Endoscopic exploration and repair of brachial plexus with telerobotic manipulation: a cadaver trial. J Neurosurg (2011) 115(3):659-64. doi:10.3171/ 2011.3.JNS10931

37. Garcia JC Jr, Lebailly F, Mantovani G, Mendonca LA, Garcia J, Liverneaux P. Telerobotic manipulation of the brachial plexus. J Reconstr Microsurg (2012) 28:491-4. doi:10.1055/s-0032-1313761

38. de Melo PP, Garcia JC, de Souza Montero EF, Atik T, Robert EG, Facca S, et al. Feasibility of an endoscopic approach to the axillary nerve and the nerve to the long head of the triceps brachii with the help of the Da Vinci Robot. Chir Main (2013) 32(4):206-9. doi:10.1016/j.main.2013.05.003

39. Facca S, Hendriks S, Mantovani G, Selber JC, Liverneaux P. Robot- assisted surgery of the shoulder girdle and brachial plexus. Semin Plast Surg (2014) 28:39-44. doi:10.1055/s-0034-1368167

40. Porto de Melo P, Miyamoto H, Serradori T, Ruggiero Mantovani G, Selber J, Facca S, et al. Robotic phrenic nerve harvest: a feasibility study in a pig model. Chir Main (2014) 33:356-60. doi:10.1016/j.main.2014.07.006

41. Miyamoto H, Serradori T, Mikami Y, Selber J, Santelmo N, Facca S, et al. Robotic intercostal nerve harvest: a feasibility study in a pig model. J Neurosurg (2016) 124(1):264-8. doi:10.3171/2015.1.JNS14603

42. Latif MJ, Park K, Razi SS, Bhora F, Todd G, Perin N, et al. Robotic microsurgical nerve grafting for sympathectomy reversal: technique and feasibility for first human case. Int J Med Robot Comput Assist Surg (2011) 7:27.

43. Coveliers H, Meyer M, Gharagozloo F, Wisselink W, Rauwerda JM, Tempesta B, et al. Robotic selective postganglionic thoracic sympathectomy for the treatment of hyperhidrosis. Ann Thorac Surg (2013) 95(1):269-74. doi:10.1016/j. athoracsur.2012.08.013

44. Naito K, Facca S, Lequint T, Liverneaux PA. The Oberlin procedure for restoration of elbow flexion with the da Vinci robot: four cases. Plast Reconstr Surg (2012) 129(3):707-11. doi:10.1097/PRS.0b013e318241287f

45. Berner S. Nerve repair. In: Liverneaux P, Berner S, Bednar M, Parekattil S, Mantovani Ruggiero G, Selber J, editors. Telemicrosurgery. Paris: Springer (2013) p. 119-22.

46. Tigan L, Miyamoto H, Hendriks S, Facca S, Liverneaux P. Interest of telemicrosurgery in peripheral nerve tumors: about a series of seven cases. Chir Main (2014) 33(1):13-6. doi:10.1016/j.main.2013.10.177

47. Taleb C, Nectoux E, Liverneaux P. Limb replantation with two robots: a feasibility study in a pig model. Microsurgery (2009) 29(3):232-5. doi:10.1002/ micr.20602

48. Huart A, Facca S, Lebailly F, Garcia JC, Liverneaux PA. Are pedicled flaps feasible in robotic surgery? Report of an anatomical study of the kite flap in conventional surgery versus robotic surgery. Surg Innov (2012) 19(1):89-92. doi:10.1177/1553350611415869

49. Maire N, Naito K, Lequint T, Facca S, Berner S, Liverneaux P. Robot-assisted free toe pulp transfer: feasibility study. J Reconstr Microsurg (2012) 28:481-4. doi:10.1055/s-0032-1313760

50. Facca S, Liverneaux P. Robotic assisted microsurgery in hypothenar hammer syndrome: a case report.ComputAided Surg(2010) 15(4-6):110-4.doi:10.3109/ 10929088.2010.507942

51. Hockstein NG, Nolan JP, O’Malley BW, Woo YJ. Robotic microlaryngeal surgery: a technical feasibility study using the daVinci surgical robot and an airway mannequin. Laryngoscope (2005) 115:780-5. doi:10.1097/01. MLG.0000159202.04941.67

52. Weinstein GS, O'Malley BW, Desai SC, Quon H. Transoral robotic surgery: does the ends justify the means? Curr Opin Otolaryngol Head Neck Surg (2009) 17:126-31. doi:10.1097/MOO.0b013e32832924f5

53. Weinstein GS, O'Malley BW, Snyder W, Sherman E, Quon H. Transoral robotic surgery: radical tonsillectomy. Arch Otolaryngol Head Neck Surg (2007) 133:1220-6. doi:10.1001/archotol.133.12.1220

54. Selber JC, Robb G, Serletti JM, Weinstein G, Weber R, Holsinger FC. Transoral robotic free flap reconstruction of oropharyngeal defects: a preclinical investigation. Plast Reconstr Surg (2010) 125(3):896-900. doi:10.1097/01. prs.0000371802.58729.30

55. Smartt JM Jr, Gerety P, Serletti JM, Taylor JA. Application of a robotic telemanipulator to perform posterior pharyngeal flap surgery: a feasibility study. Plast Reconstr Surg (2013) 131(4):841-5. doi:10.1097/PRS. 0b013e318282761b

56. Desai SC, Sung CK, Jang DW, Genden EM. Transoral robotic surgery using a carbon dioxide flexible laser for tumors of the upper aerodigestive tract. Laryngoscope (2008) 118(12):2187-9. doi:10.1097/MLG.0b013e31818379e4 
57. Mukhija VK, Sung CK, Desai SC, Wanna G, Genden EM. Transoral robotic assisted free flap reconstruction. Otolaryngol Head Neck Surg (2009) 140(1):124-5. doi:10.1016/j.otohns.2008.09.024

58. Selber JC. Transoral robotic reconstruction of oropharyngeal defects: a case series. Plast Reconstr Surg (2010) 126:1978-87. doi:10.1097/PRS. 0b013e3181f448e3

59. Garfein ES, Greaney PJ, Easterlin B, Schiff B, Smith RV. Transoral robotic reconstructive surgery reconstruction of a tongue base defect with a radial forearm flap. Plast Reconstr Surg (2011) 127:2352-4. doi:10.1097/ PRS.0b013e318213a0e4

60. Genden EM, Kotz T, Tong CC, Smith C, Sikora AG, Teng MS, et al. Transoral robotic resection and reconstruction for head and neck cancer. Laryngoscope (2011) 121(8):1668-74. doi:10.1002/lary.21845

61. Genden EM, Park R, Smith C, Kotz T. The role of reconstruction for transoral robotic pharyngectomy and concomitant neck dissection. Arch Otolaryngol Head Neck Surg (2011) 137:151-6. doi:10.1001/archoto.2010.250

62. Bonawitz SC, Duvvuri U. Robot-assisted oropharyngeal reconstruction with free tissue transfer. JReconstr Microsurg (2012) 28:485-90. doi:10.1055/ s-0032-1313758

63. Longfield EA, Holsinger FC, Selber JC. Reconstruction after robotic head and neck surgery: when and why. J Reconstr Microsurg (2012) 28(7):445-50. doi: 10.1055/s-0032-1306376

64. Bonawitz SC, Duvvuri U. Robotic-assisted oropharyngeal reconstruction with local flaps. Oper Tech Otolaryngol (2013) 24:115-9. doi:10.1016/j. otot.2013.04.001

65. Bonawitz SC, Duvvuri U. Robotic-assisted FAMM flap for soft palate reconstruction. Laryngoscope (2013) 123:870-4. doi:10.1002/lary.23578

66. Duvvuri U, Bonawitz SC, Kim S. Robotic-assisted oropharyngeal reconstruction. J Robot Surg (2013) 7:9-14. doi:10.1007/s11701-011-0326-z

67. Hans S, Jouffroy T, Veivers D, Hoffman C, Girod A, Badoual C, et al. Transoral robotic-assisted free flap reconstruction after radiation therapy in hypopharyngeal carcinoma: report of two cases. Eur Arch Otorhinolaryngol (2013) 270(8):2359-64. doi:10.1007/s00405-013-2566-1

68. Park YM, Lee WJ, Yun IS, Lee DW, Lew DH, Lee JM, et al. Free flap reconstruction after robot-assisted neck dissection via a modified face-lift or retroauricular approach. Ann SurgOncol (2013) 20(3):891-8. doi:10.1245/s10434012-2731-6

69. Song HG, Yun IS, Lee WJ, Lew DH, Rah DK. Robot-assisted free flap in head and neck reconstruction. Arch Plast Surg (2013) 40:353-8. doi:10.5999/ aps.2013.40.4.353

70. de Almeida JR, Park RC, Villanueva NL, Miles BA, Teng MS, Genden EM. Reconstructive algorithm and classification system for transoral oropharyngeal defects. Head Neck (2014) 36(7):934-41. doi:10.1002/hed.23353

71. Byeon HK, Holsinger FC, Kim DH, Kim JW, Park JH, Koh YW, et al. Feasibility of robot-assisted neck dissection followed by transoral robotic surgery. $\mathrm{Br}$ J Oral Maxillofac Surg (2015) 53:68-73. doi:10.1016/j.bjoms.2014.09.024

72. Perrenot $C$, Berengère $P$, Mastronicola R, Gangloff $P$, Dolivet G. Infrahyoid myocutaneous flap for reconstruction after robotic transoral surgery for oropharyngeal tumors. Plast Reconstr Surg (2014) 133(2):236.e-7.e. doi:10.1097/01.prs.0000437236.07930.fd

73. Lai CS, Chen IC, Liu SA, Lu CT, Yen JH, Song DY. Robot-assisted free flap reconstruction of oropharyngeal cancer-a preliminary report. Ann Plast Surg (2015) 74:S105-8. doi:10.1097/SAP.0000000000000464

74. Meccariello G, Montevecchi F, Deganello A, D’Agostino G, Bellini C, Zeccardo E, et al. The temporalis muscle flap for reconstruction of soft palate and lateral oropharyngeal wall after transoral robotic surgery. Auris Nasus Larynx (2016). doi:10.1016/j.anl.2016.11.011

75. Gorphe P, Von Tan J, El Bedoui S, Hartl DM, Auperin A, Qassemyar Q, et al. Early assessment of feasibility and technical specificities of transoral robotic surgery using the da Vinci Xi. J Robotic Surg (2017). doi:10.1007/ s11701-017-0679-z
76. Biron VL, O’Connell DA, Barber B, Clark JM, Andrews C, Jeffery CC, et al. Transoral robotic surgery with radial forearm free flap reconstruction: case control analysis. J Otolaryngol Head Neck Surg (2017) 46(1):20. doi:10.1186/ s40463-017-0196-0

77. Khan K, Dobbs T, Swan MC, Weinstein GS, Goodacre TEE. Trans-oral robotic cleft surgery (TORCS) for palate and posterior pharyngeal wall reconstruction: a feasibility study. JPlast Reconstr Aesthet Surg (2016) 69(1):97-100. doi:10.1016/ j.bjps.2015.08.020

78. Podolsky DJ, Fisher DM, Riff KWW, Looi T, Drake JM, Forrest CR. Infant robotic cleft palate surgery: a feasibility assessment using a realistic cleft palate simulator. Plast Reconstr Surg (2017) 139(2):455.e-65.e. doi:10.1097/ PRS.0000000000003010

79. Nadjmi N. Transoral robotic cleft palate surgery. Cleft Palate Craniofac J (2015) 53(3):326-31. doi:10.1597/14-077

80. Dombre E, Duchemin G, Poignet P. Dermarob: a safe robot for reconstructive surgery. IEEE Trans Robot Autom (2003) 19:876-84. doi:10.1109/ TRA.2003.817067

81. Taghizadeh F, Reiley C, Mohr C, Paul M. Evaluation of robotic- assisted platysmaplasty procedures in a cadaveric model using the da Vinci Surgical System. J Robot Surg (2014) 8(1):63-71. doi:10.1007/s11701-013-0431-2

82. Shi Y, Lin L, Zhou C, Zhu M, Xie L, Chai G. A study of an assisting robot for mandible plastic surgery based on augmented reality. Minim Invasive Ther Allied Technol (2017) 26(1):23-30. doi:10.1080/13645706.2016.1216864

83. Ciudad P, Date S, Lee MH, Lo Torto F, Nicoli F, Araki J, et al. Robotic harvest of a right gastroepiploic lymph node flap. Arch Plast Surg (2016) 43(2):210-2. doi:10.5999/aps.2016.43.2.210

84. Bowersox JC. Telepresence surgery. Br J Surg (1996) 83(4):433-4. doi:10.1002/ bjs. 1800830402

85. Ponnusamy K, Mohr C, Curet MJ. Clinical outcomes with robotic surgery. Curr Probl Surg (2011) 48(9):577-656. doi:10.1067/j.cpsurg.2011.05.002

86. Rudmik L, An W, Livingstone D, Matthews W, Seikaly H, Scrimger R, et al. Making a case for high-volume robotic surgery centers: a cost-effectiveness analysis of transoral robotic surgery. J Surg Oncol (2015) 112(2):155-63. doi:10.1002/jso.23974

87. Ind TEJ, Marshall C, Hacking M, Harris M, Bishop L, Barton D, et al. Introducing robotic surgery into an endometrial cancer service-a prospective evaluation of clinical and economic outcomes in a UK institution. Int J Med Robot Comp (2016) 12(1):137-44. doi:10.1002/rcs.1651

88. Koehn JK, Kuchenbecker KJ. Surgeons and non-surgeons prefer haptic feedback of instrument vibrations during robotic surgery. Surg Endosc (2015) 29(10):2970-83. doi:10.1007/s00464-014-4030-8

89. Hagen ME, Meehan JJ, Inan I, Morel P. Visual clues act as a substitute for haptic feedback in robotic surgery. Surg Endosc (2008) 22(6):1505-8. doi:10.1007/ s00464-007-9683-0

90. Okamura AM. Haptic feedback in robot-assisted minimally invasive surgery. Curr Opin Urol (2009) 19(1):102-7. doi:10.1097/MOU.0b013e32831a478c

91. Brahmbhatt JV, Gudeloglu A, Liverneaux P, Parekattil SJ. Robotic microsurgery optimization. Arch Plast Surg (2014) 41(3):225-30. doi:10.5999/aps.2014. 41.3.225

Conflict of Interest Statement: The authors declare that the research was conducted in the absence of any commercial or financial relationships that could be construed as a potential conflict of interest.

Copyright (c) 2017 Dobbs, Cundy, Samarendra, Khan and Whitaker. This is an open-access article distributed under the terms of the Creative Commons Attribution License (CC BY). The use, distribution or reproduction in other forums is permitted, provided the original author(s) or licensor are credited and that the original publication in this journal is cited, in accordance with accepted academic practice. No use, distribution or reproduction is permitted which does not comply with these terms. 